Враховуючи викладене, саме користувач сексуальних послуг як особа, яка придбаває, замовляє, використовує або має намір придбати чи замовити сексуальні послуги.

\title{
Література:
}

1. Цивільний кодекс України: Закон України від 16.01.2003 p. 435-IV / Верховна Рада України. URL: http:// https://zakon.rada.gov.ua/ laws/ card/435-15 (дата звернення: 12.10.2020).

2. Про захист прав споживачів: Закон України від 12.05.1991. № 1023-XII/ Верховна Рада України. URL: https://zakon.rada.gov.ua/ laws/show/1023-12/card2\#Card15 (дата звернення: 12.10.2020).

3. Про банки і банківську діяльність: Закон України від 07.12.2000. № 2121-III/ Верховна Рада України. URL: https://zakon.rada.gov.ua/ laws/card/2121-14(дата звернення: 12.10.2020).

4. Про загальну безпечність нехарчової продукції: Закон України від 02.12.2010. № 2736-VI / Верховна Рада України. URL: https:// https://zakon.rada.gov.ua/laws/show/2736-17/card2\#Card (дата звернення: 12.10.2020).

DOI https://doi.org/10.30525/978-9934-588-92-1-83

\section{ЩОДО ЗВІЛЬНЕННЯ ВІД КРИМІНАЛЬНОЇ ВІДПОВІДАЛЬНОСТІ В ЗАГАЛЬНІЙ ЧАСТИНІ НОВОГО КРИМІНАЛЬНОГО КОДЕКСУ УКРАЇНИ}

\author{
Хряпінський П. В. \\ доктор юридичних наук, професор, \\ заслужений діяч науки і техніки Украӥни, \\ професор кафедри публічного права \\ Інституту гуманітарних та сочіальних наук \\ Національного технічного університету "Дніпровська політехніка» \\ м. Дніпро, Украӥна
}

Проект Загальної частини нового Кримінального кодексу України, представлений робочою групою під керівництвом професорів Ю.В. Бауліна та М.I. Хавронюка на IV Харківському міжнародному юридичному форумі, що відбувся 23-25 вересня 2020 р., в частині відмови від інституту звільнення від кримінальної відповідальності викликає 
суперечливі почутті та сумніви щодо своєчасності таких радикальних змін в кримінальному законодавстві України. В проекті Загальної частини Кримінального кодексу України (далі - КК) загалом дуже рідко використовується сталий термін «кримінальна відповідальність», а звільнення від кримінальної відповідальності пропонується змінити на звільнення від покарання (Розділ 3.3. проекту) [1].

Через запропоновані новації, на наш погляд, арсенал кримінальноправових заходів заохочення позитивної посткримінальної поведінки суттєво збідніє та знизиться його ефективність. Нами неодноразово зверталася увага на неоднорідність правової природи звільнення від кримінальної відповідальності, що передбачається в Загальній частині чинного КК, та спеціальними видами звільнення в його Особливій частині [2, с. 273-274; 3, с. 899]. Передусім, звернемо увагу, що в чинному КК кількість звільнення від кримінальної відповідальності, передбачених у кримінально-правових приписах збільшилася в півтора рази, - 317 до 28 видів. Цей напрям розвитку законодавства про кримінальну відповідальність $є$ перспективним, оскільки віддзеркалює європейський шлях гармонізації кримінального права, практичну реалізацію принципів гуманізму та економії кримінальної репресії. Кримінальна відповідальність та покарання як «ultimo ratio» (останній захід - П.Х.) впливу на особу, яка вчинила злочин, не завжди виконує завдання виправлення винного та запобігання вчиненню нових злочинів. У сучасних умовах глобалізації та ідеології постмодерну принцип невідворотності кримінальної відповідальності в європейському та світовому правовому просторі зазнає раціональної модифікації.

У якості основного аргументу проти звільнення від кримінальної відповідальності у проекті нового КК вказують на його ніби то невідповідність ст. 62 Конституції України. Так, С.С. Яценко, який послідовно звертав увагу на цю проблему, вважав, що питання наявності підстав для настання кримінальної відповідальності можливе лише при встановленні в діянні особи складу злочину, в тому числі й такого його важливого компонента, як вина особи у вчиненні злочину, що відповідно до конституційного припису (ч. 1 ст. 62 Конституції України) можливе лише обвинувальним вироком суду. Закриття ж кримінальної справи ухвалою або постановою суду без постановлення обвинувального вироку, яким тільки і може бути встановлена вина особи у вчиненні злочину, вочевидь не узгоджується з конституційним принципом презумпції невинуватості» [4].

Згідно ч. 2 ст. 44 КК звільнення від кримінальної відповідальності у випадках, передбачених цим Кодексом, здійснюються виключно судом. Порядок звільнення від кримінальної відповідальності встановлюється 
законом. Відповідно до ч. 1 ст. 285 КПК України особа звільняється від кримінальної відповідальності у випадках, передбачених законом України про кримінальну відповідальність. Відповідно до ч. 1 ст. 124 Конституції України правосуддя в Україні здійснюється виключно судами. Закриття кримінальної справи зі звільненням особи від кримінальної відповідальності - це не що інше, як акт відправлення правосуддя, а тому закріплений у ст. 44 КК і ст. 285 КПК України судовий порядок звільнення особи від кримінальної відповідальності узгоджується з наведеним конституційним приписом.

Ми солідаризуємося із поглядом О.О. Дудорова, який вважає, що Конституція України не дає прямої відповіді на питання про те, в якому порядку має встановлюватись винуватість особи у вчиненні злочину, якщо цій особі кримінальне покарання не призначається [5, с. 42]. На погляд Ю.В. Бауліна, ч. 1 ст. 62 Конституції України не виключає того, що суд може визнати особу, яку звільняють від кримінальної відповідальності, такою, яка вчинила злочин, у процесуальному порядку, що відрізняється від винесення обвинувального вироку $[6,54-55]$. Отже, вітчизняні вчені стверджують, що здійснюване судом звільнення від кримінальної відповідальності з формальної точки зору частині 1 ст. 62 Конституції України не суперечить, а твердження окремих вітчизняних авторів про невідповідність інституту звільнення від кримінальної відповідальності конституційному принципу презумпції невинуватості навряд чи можуть вважатись переконливими.

Наступним аргументом щодо заміни звільнення від кримінальної відповідальності на звільнення від покарання є та обставина, що певне коло чинних кримінальних законів країн-учасників РС не використовує конструкцію «звільнення від кримінальної відповідальності», як i загалом мало використовує термін «кримінальна відповідальність», віддаючи перевагу «кримінальному покаранню» та звільненню або пом'якшенню останнього у разі вчинення винною особою комплексу позитивної посткримінальної поведінки [7, с. 399-404]. Саме така правова позиція підтримується у висновках Венеціанської комісії, що були оприлюднені на Міжнародній науковій конференції, що відбулася в м. Харків 17-19 жовтня. 2019 р. Так, доктор Фабіан Льовенберг, керівник компоненту з питань верховенства права Консультативної місія Європейського Союзу в Україні, наголосив на об’єднанні положень усіх релевантних міжнародних конвенцій, ратифікованих Україною, та включення їх до Кримінального кодексу України. Уносячи зміни до Кримінального кодексу, важливо брати за основу міжнародні стандарти, визначені в багатосторонніх конвенціях ООН та Ради Свропи (зокрема, з огляду на процес асоціації України з $\mathrm{CC}$, 334 
важливо, щоб деякі визначення злочинів були узгоджені із мінімальними нормами $Є С$ щодо складу кримінальних правопорушень та покарань у сфері транскордонної злочинності, особливо за такі тяжкі злочини, як тероризм, торгівля людьми, сексуальна експлуатація жінок та дітей, незаконний обіг наркотиків, незаконний обіг зброї, відмивання грошей, корупція, підробка платіжних засобів, кіберзлочинність, організована злочинність, деякі екологічні злочини та злочини, пов'язані з расизмом і ксенофобією) [8, с. 18].

Разом із тим, багато країн СС в кримінальних кодексах (спеціальних законах) досить широко використовують звільнення від кримінальної відповідальності у якості кримінально-правових заходів впливу на осіб, які , за звичай, вперше вчинили злочини невеликої та середньої тяжкості. Скажімо, Розділ IV КК Чеської Республіки «Звільнення від кримінальної відповідальності» передбачає звільнення від кримінальної відповідальності у зв'язку із дійовим каяттям [9]. В КК Республіки Польща Розділ III Загальної частини також передбачає декілька різновидів звільнення від кримінальної відповідальності [10]. Водночас, вказані та інші КК багатьох країн $С$ п поруч з звільнення від кримінальної відповідальності мають в своєму арсеналі кримінальноправових заходів впливу й звільнення від покарання. Наразі суддя Конституційного Суду Латвійської республіки у відставці, професор юрфаку Ризького університету ім. Паула Страдиня (Rīgas Stradiña universitāte) Кайа Сандра (Kaija Sandra) на Міжнародній науковій конференції, що відбулася в м. Харків 17-19 жовтня 2019 р. відповідаючи на запитання, дала однозначно зрозуміти що у Венеціанської комісії з цього приводу немає заперечень до чинного КК Латвійської республіки та практики його застосування в частині звільнення від кримінальної відповідальності.

В Україні склалася практика, що доводить позитивну динаміку застосування судами України звільнення осіб, стосовно яких суди закрили провадження у справах, за постановами (ухвалами), що набрали законної сили. Так, в 2013 р. кількість таких осіб збільшилася порівняно з 2012 р. і становила 22,8 тис.: 3 примиренням винного 3 потерпілим 7,6 тис. осіб, або 33,5 \% (16,9 \% - 2012 р.) від кількості тих, щодо яких справи закрито; зі зміною обстановки - 1,3 тис. осіб, або

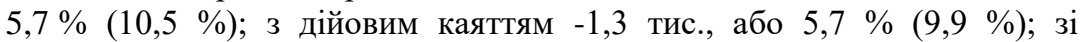
смертю - 1,3 тис. осіб, або 5,7 \% (7,5\%); із передачею особи на поруки - 946, або 4,1 \% (7,6 \%); з амністією 785 осіб, або 3,4 \% $(19,1 \%)$. У тому числі у справах публічного обвинувачення було закрито провадження стосовно 13,7 тис. осіб (18,6 тис.), із них у зв'язку 3 примиренням винного 3 потерпілим - 2,9 тис. осіб, або 21,1\% 
(12,2\%). У 2015 році за судовими рішеннями, що набрали законної сили, стосовно 18,3 (21,7 - 2014 р.) тис. осіб кримінальні провадження закрито. За судовими рішеннями, що набрали законної сили у 2016 р., стосовно $16,8(18,3)$ тис. осіб кримінальні провадження закрито. За судовими рішеннями, що набрали законної сили у 2017 р., стосовно $19,7(16,8)$ тис. осіб справи кримінальні провадження закрито [11]. Відтак кримінально-правова доктрина і судова практика виявляє стабільний інтерес до звільнення від кримінальної відповідальності та доступу до правосуддя у частині застосування закриття кримінального провадження із звільненням від кримінальної відповідальності. Підсумовуючи вищевказане, вважаємо, що у проекті Загальної частини нового Кримінального кодексу України звільнення від кримінальної відповідальності має залишитися як варіант вирішення кримінальноправового конфлікту до обговорення.

\section{Література:}

1. Кримінальний кодекс України (проект): контрольний текст (станом на 15 вересня 2020 p.) file:///C:/Users/Admin/Desktop/ 1-kontrolnyj-proekt-kk-15-09-2020.pdf

2. Яценко С. Конституційний принцип презумпції невинуватості та інститут кримінальної відповідальності в праві України і деяких інших європейських держав: порівняльний аспект // Юридичний вісник України. 2004. № 43. 23-29 жовтня.

3. Хряпінський П.В. Доступ до звільнення від кримінальної відповідальності у контексті судової реформи: матеріали загальнонаціонального юридичного форуму «Доступ до правосуддя у контексті судової реформи» (25 травня 2018 р., Сєверодонецьк) : матер. загальнац. юрид. форуму (м. Сєверодонецьк, 25 травня 2018 р.). К.: Baiте, 2018. 312 c.

4. Хряпінський П.В. Заохочувальні норми у законодавстві України про кримінальну відповідальність. Велика українська юридична енциклопедія. У 20-ти томах. Том 17. Кримінальне право / Ред. 17-го тому: Тацій В.Я., Борисов В.І., Тютюгін В.І. та ін. Харків : Право. 2017. - 1064 p.;

5. Баулін Ю.В. Звільнення від кримінальної відповідальності : моногр. К.: Атіка, 2004. 296 с.

6. Дудоров О. Про конституційність інституту звільнення від кримінальної відповідальності // Вісник Національної академії прокуратури України. 2009. № 1. С. 40-48. 
7. Хавронюк M.I. Кримінальне законодавство України та інших держав континентальної Свропи: порівняльний аналіз, проблеми гармонізації : моногр. К.: Юрисконсульт, 2006. 1048 с.

8. Концептуальні засади нової редакції Кримінального кодексу України : матеріали міжнар. наук. конф., м. Харків, 17-19 жовт. 2019 р. / редкол.: В.Я. Тацій (голов. ред.), А.П. Гетьман, Ю.В. Баулін та ін. Харків : Право, 2019. 500 с.

9. Кримінальний кодекс Чеської Республіки / Переклад на українську мову О.В. Коротюк. К. : ОВК, 2020. 264 с.

10. Кримінальний кодекс Республіки Польща / Під ред. В.Л. Менчинського. Переклад на українську мову В.С. Станіч. К. : OBK, 2016. 138 c.

11. Огляд даних про стан здійснення правосуддя у 2012-2017 pp. Електронний ресурс // Інформаційний сервер Верховного Суду України. Режим доступу: https://court.gov.ua/userfiles/ogliad_2012-2015, 2016, 2017.pdf 